\title{
Intelectuais e vida cultural em Londrina-PR (1950-1979)
}

Intellectuals and cultural life in Londrina-PR (1950-1979)

Claudinei Carlos Spirandelli

RESUMO: O artigo diz respeito a intelectuais ou produtores de cultura de uma média cidade brasileira do Sul (Londrina-PR), que nela desenvolveram trabalhos (de literatura, imprensa, empreendimentos culturais, educação), nas décadas de 1950 1970. A pesquisa trata desses intelectuais no que concerne às estratégias que manejaram para se projetar e conquistar "mercados", sendo investigados aspectos de suas trajetórias de vida (origens sociais, formações educacionais, atuações políticas etc.). A metodologia centra-se em manusear biografias (reconstruídas a partir de livros, jornais, internet, obras acadêmicas e literárias). São utilizados como referenciais teóricos conceitos de Bourdieu, principalmente. O objetivo é verificar correspondências entre origens sociais, habitus e capitais de intelectuais com suas conquistas e produções. Procuramos ver na cultura elemento privilegiado para fornecer interpretações sociológicas sobre a vida social maior.

PALAVRAS-CHAVE: campo intelectual; História intelectual; Sociologia da cultura; Sociologia da vida intelectual; Londrina (PR).

\begin{abstract}
The article refers to intellectuals or producers of culture from an average Brazilian city of the South (Londrina-PR), who developed works (literature, press, cultural enterprises, education) in the 1950s to 1970s. it deals with these intellectuals in what concerns the strategies they have managed to project themselves and to conquer "markets", investigating aspects of their life trajectories (social origins, educational formations, political actions etc.). The methodology focuses on handling biographies (reconstructed from books, newspapers, the internet, academic and literary works). Concepts of Bourdieu, mainly, are used as theoretical references. The objective is to verify correspondences between social origins, habitus and capitals of intellectuals with their achievements and productions. We seek to see culture as a privileged element in providing sociological interpretations of the larger social life

KEY WORDS: intellectual field; Intellectual history; Sociology of culture; Sociology of intellectual life; Londrina (PR).
\end{abstract}


No final da década de 1920, a Companhia de Terras Norte do Paraná (CTNP), subsidiária da empresa inglesa Parana Plantation, instala-se na região norte do estado do Paraná e adquire milhares de alqueires para um projeto de exploração, já iniciado com a vinda de compradores de terras ingleses. Logo chegam alemães, italianos, espanhóis, japoneses, judeus alemães, eslavos, poloneses etc., além de brasileiros de diversos estados.

Londrina, centro da região, é oficialmente fundada em 1934: ainda sem sistema de esgoto, as ruas principais são de terra (tornando-se lama quando chovia); galinhas, porcos, cavalos, vacas perambulam livremente pela cidade; pães e outros alimentos são feitos nas próprias casas; roças ficam perto das residências urbanas; abundam profissões de caráter rural, como as de seleiro, ferreiro, amolador, açougueiro etc. (CERNEV, 1995; IPAC, 1993). O setor agrário é o principal elemento econômico local, e o café o principal cultivo. Em 1940, havia 11.175 pessoas na área urbana, e 19.103 na área rural. Em 1950, os números eram de 34.230 e 37.182, respectivamente. Em 1960, a área urbana atinge a cifra de 77.382 pessoas e a rural vai para 57.439. Já em 1970, a área urbana possui 163.528 pessoas e a rural por 64.573 (PREFEITURA DE LONDRINA, 2015).

A população, com origem indígena, negra, europeia, asiática, encontra-se entrelaçada e com características étnicoculturais diluídas. Os laços de pertença, nesse sentido, são frouxos; num contexto como este, características e significados tradicionais não se impõem tanto, tornam-se obsoletos, possibilitando surgir novos sentidos e significados.

O quadro introdutório, com as transformações ocorridas na sociedade londrinense, é necessário para o entendimento da atuação cultural no local e para expor o cerne da pesquisa que origina este artigo. Assim, os intelectuais, letrados ou produtores de cultura enfocados - escritores, jornalistas, empreendedores culturais - são aqueles indivíduos que residiam na cidade e nela desenvolviam trabalhos em literatura, poesia, artigos e crônicas na imprensa e empreendimentos culturais e educacionais. E os critérios para a filtragem dos nomes deram-se da seguinte forma:

- ser famoso/prestigiado na época e relembrado posteriormente;

- ter se destacado nas áreas literária, educacional ou política;

- ter publicações/obras relevantes e comercializáveis;

- ter menções em meios eletrônicos (internet);

- ter produção ainda em voga (em bibliotecas públicas ou livrarias);

- ter integrado alguma rede (de amizade, profissão, coleguismo, militância, religião etc.).

Outro critério para a pesquisa diz respeito ao fato de os intelectuais pesquisados serem distribuídos em uma formação geracional posta a partir das datas de seus nascimentos (de meados 
${ }^{1}$ Listagem feita a partir do livro de Carlos Francovig (2005), com cerca de sete dezenas de nomes que atuaram, de louma forma, no período: Adelino ande

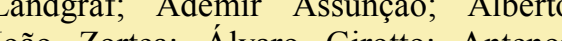
oão Zortea; Alvaro Girotto; Antenor Bertone Jr., Carlos Alberto Parreira Goulart; Carlos Alberto Verçosa Silva; Cassio Leite Machado; Cleusa Antonia; David Schosque Ono; Delio Cesar Domingos Pellegrini Jr.; Donato Parisotto; Dorival Zemuner; Dulcineia Novaes Felizardo; Dulcínie Trigueiros; Edison Maschio; Edmilson Molina; Elga Nascimento Pinto; Evandro Ribeiro da Nascimento Pinto, Evandro Ribeiro da Silva; Floriano Mendes; Francisco Pereira de Almeida Jr., Geraldo Fernandes (Dom); Hamilton Faria; Hilton Luiz Libos; Humberto Puiggari Coutinho; João Antonio Ferreira Filho; João Soares Caldas; Joel Dutra; José Antonio Tadeu Felismino; José Augusto; José Eduardo Siqueira; José Leite de Carvalho; Josen Maria de Oliveira; Leonardo Prota Lourival Alves Pontidura; Luiz José Maia; Luiz Antonio de Souza Castro Maia, Luiz Antonio de Souza Castro Hir, Luiz Cordoni Jr.; Marcelo Heij Oikawa; Marcos Antonio Moreira (Villa), Maria Aparecida Miranda; Maria da Conceição Cardoso; Maria Giovanni; Maria Leopoldina Rezende; Marinósio Trigueiros Filho; Mario José Romagnolli; Marta Maria Basso; Mauro Ticianelli; Miriam Paglia Costa; N. Meirelles; Nair Paglia Piantini; Nelson Capucho; Nelson Monteiro Menezes; Nelson Sato; Neusa Aparecida Casagrande; Nitis, Neusa Aparecida Casagrande, Nitis Jacon; Norma Shirakura; Octavio Telles Rudge Maia; Paulo Domingues de Assis; Paulo Roberto Nassar; Pedro Barros; Pedro Roberto Ferreira de Barros; Raimundo Caruso; Reinoldo Atem; Richard de Carvalho; Roldão Oliveira Arruda; Rubens Lemos; Seicho Tokunaga; Sérgio Farias Elias; Valdeci dos Santos; Vicente Vianna; Vilmári Moratore Trigueiros; Wellington Moreira; Zaqueu de Melo.

Dossiê Arte do Carnaval

Arquivos do CMD, Volume 6, N.1. Jul/Dez 2017 perfeito e autônomo seria muito difícil; a menção que aqui se faz é um ponto de vista analítico.

A proposição inicial indaga ao objeto: por que esses londrinenses quiseram tanto fazer literatura e/ou empreendimentos culturais, educacionais e gêneros jornalísticos? Por que fazer nesses formatos? Como tais produtores de cultura "se inventaram" num momento e local ainda sem condições de demanda para a obra que desenvolviam? E quais as estratégias de atuação e de sobrevivência para atores sociais situados tão distantes de capitais e grandes centros (onde as coisas poderiam se dar de modo diferente e menos difícil)? Tudo isso fez com fosse desenvolvida a questão principal da pesquisa: quais as motivações que engendraram, nesses intelectuais, os direcionamentos de projetos, interesses empreendedorísticos, rebeldias, aceitações-conciliações literárias e políticas?

Assim, supomos que motivações girando em torno da obtenção de prestígio e empregabilidade ou mercado consumidor (para suas obras e empreendimentos) poderiam ser um bom começo para nossas explicações e interpretações. Frisemos isso pelo fato de procurarmos entendimentos sobre intelectuais no que se refere a aspectos objetivos de suas vidas materiais (indústria editorial, de financiamentos, de gravação, distribuição, divulgação, obtenção de cargos e empregos públicos etc.).

Metodologicamente, enquanto técnica de obtenção de dados, fizemos uso de pesquisa bibliográfica (em artigos 
${ }^{2}$ Como o da contribuição de Nitis Jacon e de Delio Cesar, cuja atração por eles criada, o Festival Internacional de Teatro de Londrina (FILO), extrapolou as fronteiras londrinenses e se transformou em referência de festivais de teatro pelo país e pelo mundo.

3 Para o estudo, foram examinadas informações sobre as trajetórias dos intelectuais referidos às suas tentativas de entrar e/ou sobreviver em um campo (e dados estes inseridos nos habitus do mesmos e esgrimidos em "capitais"), e dentro de uma variação temporal por nó estabelecida, a da segunda metade do século XX na cidade de Londiade do século XX na cidade de Londrina. Ess noção bourdiana de campo, que orient uma pesquisa, diz respeito a un constructo teórico que substitui a ideia de sociedade; ela é um recorte da realidade, um espaço social institucionalizado, onde se dão todas as práticas sociais; um lócus onde afloram ou se manifestam posições de poder e de trocas simbólicas, com relações de força e de disputas cujos intuitos são beneficiar quem nesse campo ne campo se enreda, ou seja, os diferentes agentes as instituições que o produzem e reproduzem (ORTIZ, 2002). Cada agente do campo é caracterizado pela trajetória social, habitus e posição nele. E como todo campo possui um "objeto de desejo (posses que agregam ao detentor certo poder social) acabam ocorrendo nele disputas por poder e influência. E essas relações com disputas, constrangimentos, exigências, necessidades e demantos, exigências, necessidades e demandas de grupos sociais acabam tambem po balizar a produção do intelectual
(BOURDIEU, 1974; 1996).

No caso, conceitos e raciocínios de Max Weber (letrados chineses, estratificação social; rotinização) (WEBER, 1963; 1963b; 1999) e de Karl Mannheim, como o de geração (MANNHEIM, 1982). científicos, livros e teses) e pesquisa documental (fontes primárias e secundárias, informações de jornais, revistas, sites e obras literárias). Esses dados (contendo experiências e visões dos atores sobre status, valores, ideários etc.) foram sistematizados e trabalhados, na medida do possível, a partir de: ano e local de nascimento; grupo/classe social de origem; situação econômica da família; relações de parentesco e matrimônios; formação cultural e experiências intelectuais; empregos; carreira política e militâncias; traços individuais ("talentos"); vivências em comum, com alianças e disputas. Isso tudo permitiu que as biografias fossem reconstruídas.

Essas informações foram também imbricadas, mas secundariamente, às produções dos intelectuais envolvidos, pelo fato de o foco do trabalho não ser as obras (romances/contos; poesias, canções, empreendimentos culturais, educacionais, religiosos, crônicas jornalísticas etc.) dos intelectuais, mas as relações sociais em que se enredaram e que os tornaram reconhecidos nos meios culturais, políticos e sociais da cidade. $\mathrm{Ou}$ seja, o interesse aqui não é o que produziram, mas em que condições sociais o fizeram. Mas é importante expor que nossos estudos têm por peculiaridade e ineditez o perscrutar da contribuição de intelectuais/letrados locais para o desenvolvimento de uma "literatura" para a cidade ${ }^{2}$.
Como fundamentação teórica, expomos que, por toda essa gama de objetos, problematizações e perspectivas, a pesquisa insere-se, de modo amplo, nos domínios da sociologia da cultura e, mais especificamente, na área da sociologia da vida intelectual. Esta área elege como tema principal de reflexão os chamados intelectuais (artistas, cientistas e grupos de elite em geral) no que concerne às suas trajetórias de vida e carreiras, articulando-as a dimensões como: as origens sociais dos atores (suas famílias, classes, grupos de status etc.), suas obras/feitos, as disputas em suas áreas de atuação (as relações profissionais e pessoais em ambientes intelectuais, como universidades, partidos, igrejas e outras instituições), o mercado da cultura (indústrias editoriais e de gravação, divulgação e distribuição; comercialização de obras; financiamentos; benesses e cargos etc.). A área recupera os contextos sociais amplos que conformam o mundo dos diálogos e tensões travados por esses indivíduos e suas obras (ARRUDA, 2001). E o principal autor ligado a esses domínios e áreas e constituidor dos referenciais teóricos originadores das perspectivas analíticas deste texto é Pierre Bourdieu (com o central conceito de campo, mas também os de habitus e capital) ${ }^{3}$, entre outros ${ }^{4}$.

\section{A produção cultural literária em Londrina}

Pontuada com a história da cidade, pode-se dizer que a produção cultural literária local também se inicia na década de

Dossiê Arte do Carnaval

Arquivos do CMD, Volume 6, N.1. Jul/Dez 2017 
5 O primeiro caso "citável" é o de José Leite de Carvalho, oriundo de Pindamonhangaba (SP). Não temos seus registros de nascimento e morte; apenas sabemos que era pedreiro, e que atuou na construção de pontes, viadutos e estradas: semianalfabeto, boêmio, animador de festas, ele cantava, tocava violão, compunha marchas tocava violão, compunha marchas carnavalescas, (FRANCOVIG, 2005, p. 12). Essepular" (FRANCOVIG, 2005, p. 12). Esse artis compôs, em 1934, a primeira march carnavalesca sobre a cidade. Mas ele seria apenas mais trovador que literato.

${ }^{6}$ Teve como representante em Francisco Pereira de Almeida Jr.; autor da letra de um hino à cidade, a sua "produção" é, na maioria, de teor humorístico: fazia sonetos, quadras, trovas, transformando notícias em caricaturas literárias. Er quase um cartunista literário (FRANCOVIG, 2005, p. 17), no jornal Folha de Londrina. Houve também letrados que publicaram pequenos livros de poemas e crônicas, em edições curtas, precárias, de tiragem limitada financiadas pelo próprio bolso dos autores, supomos São os do autores, supomos. São os casos do cronista curtibano José Augusto (auto do livro de poemas Cantigas (1951); Floriano Mendes (Silhuetas); Octavio Telles Rudge Maia (Ninho de ratos; Caixeiros viajantes) e Zaqueu de Melo (Crônicas e ensaios religiosos), todos com obras desse naipe vindo a lume em meados da década de 1950 (FRANCOVIG, 2005, p. 24-6).

7 Os textos, feitos por secundaristas e universitários, e vendidos nas ruas, na universitálos, e vendings nas ruas, não passavam de folhetins datilografados xerocopiados, com poemas, crônicas, "críticas literárias" e quase nada em prosa (o tamanho e o preço alto dessas publicações limitavam tal produção, naturalmente). Outra "entidade literária" da época é o Grupo Aberto de Literatura (GAL), criado pelo centro acadêmico do

Dossiê Arte do Carnaval

Arquivos do CMD, Volume 6, N.1. Jul/Dez 2017 também baixa rentabilidade); ao mesmo tempo, era uma forma de estar empregado (FRANCOVIG, 2005, p. 124-7).

Os grupos literários rebeldes, com o espírito voluntarioso de seus integrantes e o apoio do escritor Marinósio Trigueiros Filho, fazem surgir o I Mural de Poemas, no ano de 1976. O primeiro de muitos, agora com alguma promoção e incentivo do poder público municipal. Também nessa década surge a Editora Cooperativa dos Escritores, com literatos de Londrina, Curitiba e São Paulo, que publica livros (de poesias) e folhetins (de poesias e contos), bem como publica obras coletivas (de poemas e contos); os conteúdos, de modo geral, também são “marginais” (FRANCOVIG, 2005).

No esteio dos murais e clubes de serviço da cidade (como o Rotary e o Lions Club), é criada, em 1978, a Academia de Letras, Ciências e Artes de Londrina, uma sociedade civil de direito privado sem fins lucrativos, onde se discute literatura, línguas, artes, ciência, cultura e se divulgam textos dos integrantes. Entre os fundadores estão João Soares Caldas, Marinósio Trigueiros Filho, Mario José Romagnolli (FRANCOVIG, 2005). A revista mensal da entidade é a Almenara, surgida em 1980. Com o crescimento da agremiação, surge uma "filial", a Casa do Poeta de Londrina, em 1983, também com uma publicação mensal, a Poesia \& Cia. Ambas as entidades promovem poesias, recitais, concursos, divulgam nomes locais e regionais de escritores e publicam livros financiados pelos autores ou patrocinadores. 
curso de Medicina da Universidade Estadual de Londrina (UEL), que também publica folhetins mimeografados que são financiados por docentes da universidade, livrarias, e cursos (pré-vestibulares e de línguas estrangiras). Dele origina e de Grupo Base de Lite (GBL), de Grupo Base de Literatura (GBL), de estudantes de humanidades da mesma universidade (FRANCOVIG, 2005, 120). Para mais informações sobre a vida cultural de Londrina do período, $c f$. LEITE, 2012; MARINHO, 2005; MEIRA, 2008; MENDONÇA, 2006.
Assim, tropicalismo, arte marginal-transgressora, repressão, censura, governo militar, crítica ao poder, crítica a instituições, precariedade artesanal, arte de fundo de quintal são todos signos sob os quais se processa a "literatura" londrinense dos anos 1970

Nos anos 1980, surgem outros grupos de atividades literárias, predominando a poesia urbana, em linguagem fragmentada e estética "anárquica", tal como na seção Leitura, do jornal Folha de Londrina; continuam as exposições, recitais, murais, os poemas em revistas literárias precárias e publicações de livros de poemas de autorias coletivas (FRANCOVIG, 2005, p. 130-5) .

Após os anos 1990, a situação estará diferente: a ampliação dos investimentos educacionais pelo Estado, apesar de precária, faz aumentar o público leitor e consumidor de jornais, revistas e livros redesenhando-o. Isso vale para a cidade ${ }^{8}$ e para o país.

\section{Trajetórias}

A área cultural da cidade, desde os anos 1950, resume-se a alguns poucos cinemas, conservatórios musicais, grupos de teatro, pequenas exposições; some-se a isso o FILO, após o final da década de 1960. Ou seja, Londrina tinha, na época considerada para a pesquisa, um sistema incipiente e pouco diferenciado de instituições culturais. A cidade também não dispunha de rotina literária em revistas dessa área. Rotina esta que requer esquema sistemático de "linha de montagem industrial": poucos bons escritores e uma maioria de medianos esforçados e "produtivos" para reproduzir a revista e tocá-la adiante. Londrina também não possuía produtores profissionais ou especializados (escritores plenos) e empresários editoriais do ramo. Lembremos que indústria editorial obriga o intelectual/artista a uma completa institucionalização, rotinização e racionalização de sua vida nessa seara.

O que a cidade dispõe, mas precariamente, é de instâncias de consagração, ou seja, entidades reais ou "virtuais", compostas por críticos, agentes de disseminação, mecenas, "padrinhos", amizades na imprensa, no poder, em partidos políticos, empresas públicas e privadas, instituições de ensino, igrejas etc., que constroem celebração, reconhecimento, visibilidade, prestígio e distinção, o que acaba ajudando o intelectual/artista a conseguir produção, financiamento, difusão e distribuição de suas obras. Mas apenas isso seria pouco.

A outra necessidade é existir um mercado propriamente dito para o intelectual/letrado, com público leitor formado, algo de que também a cidade não dispõe. O que é possível ao profissional londrinense da área, como fonte de renda, é ater-se ao poder público, a alguma instituição (universidade, Igreja, empresa, 
partido político, "padrinho" poderoso etc.), ou atuar na grande imprensa.

Em tais sentidos, poderemos agora entender melhor essa configuração com as trajetórias modelares a seguir.

\section{Mario José Romagnolli}

Como primeiro nome temos Mario José Romagnolli, poeta, vereador, empresário do ramo marmorista e escultor, nascido em Boa Esperança (MG), em 1906, e falecido em Londrina em 1991. Veio para a cidade em 1938. Casou-se com Iolanda Maiomonei, com quem teve extensa família de dezoito filhos.

Em Londrina, foi vereador por dois mandatos pelo Partido Socialista Brasileiro, o PSB (1947-51 e 1951-55); disputou a eleição para a Prefeitura em 1955, mas não se elegeu. Abriu a primeira marmoraria da cidade, foi escultor, construtor de casas e prédios importantes (o da Associação Comercial de Londrina e o da igreja matriz em estilo barroco da vizinha cidade de Arapongas-PR, por exemplo) e proprietário de terras. Entre as curiosidades em torno de sua vida estão o fato de um dos cemitérios da cidade, o São Pedro, possuir dezenas de lápides com seus poemas (PEDRIALLI, 2012).

Era um poeta popular, segundo Francovig (2005, p. 124) Costumava perambular pelas ruas da região central da cidade e, encontrando algum amigo, presenteava-o com poemas que dizia ter escrito para essa pessoa; fez, na maioria, sonetos publicados em folhetins (PEDRIALLI, 2011). Deixou boa parte dessa produção organizada em A doce vingança do poeta. Estimam-se em 5.000 os poemas que compôs (PEDRIALLI, 2012). Também fez parte do grupo que, em 1978, fundou a Academia de Letras, Ciências e Artes de Londrina, com Marinósio Trigueiros Filho, João Soares Caldas e outros (FRANCOVIG, 2005).

Suas outras obras registradas são: Ler cantando (poesia) (1971); Contos e poesias (1982); Conheça o Brasil pela poesia (1988); Fragmentos da alma: poesia. (s/d) e Vibramos com a poesia $(\mathrm{s} / \mathrm{d})$.

\section{Dom Geraldo Fernandes}

Outro nome importante da cidade é Dom Geraldo Fernandes Bijos, nascido em Contagem (MG), em 1913, e falecido em Londrina, em 1982. Origina-se de família humilde: aos nove anos morre seu pai e o menino faz pequenos trabalhos para ajudar no sustento da família. Ainda na juventude, ingressa no seminário claretiano Congregação dos Filhos do Imaculado Coração de Maria, na cidade de São Paulo (SP), onde emite os votos religiosos, ainda em 1929. Ordena-se padre em Roma, em 1936, onde também realiza seu doutoramento, na área de Direito Canônico 
(CAVALHEIRO, 2013). Toda essa formação o ajuda a se tornar reitor do Instituto Teológico de Curitiba (PR)

Sagra-se bispo em 1957, no Santuário do Imaculado Coração de Maria, na capital paulista. Toma posse da diocese de Londrina nesse mesmo ano, tornando-se o primeiro bispo da cidade. Em 1970, é elevado a arcebispo da arquidiocese da cidade.

Dom Geraldo Fernandes estimula o espírito acadêmico universitário em Londrina: cede dependências da catedral do município para o curso de Odontologia; ajuda na criação de faculdades isoladas e de uma universidade estadual para a cidade; ajuda na fundação do Instituto Agronômico do Paraná (IAPAR); leciona Direito Canônico na então Faculdade Estadual de Direito, de Londrina; organiza "escolas radiofônicas" para alfabetizar os trabalhadores rurais, dentro do Movimento de Educação de Base (MEB), bem como funda a rádio Alvorada, com os mesmos intuitos; e faz programas diários na TV Coroados, a qual também ajudou a trazer para a cidade (BRANDES, 2013).

Tem grande engajamento político e social no estado do Paraná: é presença constante em inaugurações, exposições, reivindicações da comunidade, recepção de pessoas importantes etc.; está entre os fundadores da Congregação das Missionárias de Santo Antônio Maria Claret, em Londrina, em 1958 (CAVALHEIRO, 2013). Segundo o historiador Reginaldo
Fernandes (2012), o religioso se liga à ala "anticomunista" da Igreja Católica, sendo favorável ao movimento militar e governo pós-1964; aliás, Dom Geraldo Fernandes ajuda a fundar, em 1961, a Frente Agrária do Paraná (FAP), entidade que, por sua vez, conta com a simpatia de jesuítas e da entidade católica Tradição, Família e Propriedade (TFP) (FERNANDES, 2012, p. 112-3; 128).

Dom Geraldo Fernandes mantém também fortes relações com a Conferência Nacional dos Bispos do Brasil (CNBB), sendo seu vice-presidente, membro da comissão de juristas da instituição e assessor dos Tribunais Eclesiásticos do Brasil. Também atua como membro da Comissão Preparatória do Concílio Vaticano II. Segundo o religioso Dom Orlando Brandes (2013), Dom Geraldo Fernandes pedira uma licença ao Papa para deixar o cargo de bispo de Londrina e ser missionário na África. O Papa não permite, mas nomeia-o assessor das Congregações Religiosas femininas no Brasil, talvez como consolação. Mas Dom Geraldo Fernandes teria mantido a esperança de um dia atuar nesse continente (BRANDES, 2013).

Registram-se, entre seus escritos, diversos artigos religiosos na Revista Eclesiástica Brasileira, Revista dos Religiosos do Brasil e no jornal Voz do Paraná. 
9 "Zaqueu consegue os primeiros cursos superiores para a cidade, contra a vontade do bispo de Jacarezinho, D. Geraldo Sigaud, que pressionou os deputados para que rejeitassem o projeto de "A que rejeissem o projeto de lei. "A faculdade seria de protestantes", alegou. Diretor do Instituto Filadélfia, Zaqueu fez uma alteração: não será evangélica nem particular, mas pública. "Driblou" o bispo e obteve a aprovação, em 25 de janeiro de 1956: Faculdade Estadual de Filosofia, Ciências e Letras" (SCHWARTZ, 2017).

\section{Zaqueu de Melo}

O próximo nome importante de nosso estudo é o de Zaqueu de Melo, nascido em Monte Carmelo (MG), em 1914, e falecido em Londrina, em 1979. É filho de Manuel de Melo e de Maria Eulina de Mendonça (ambos de Bagagem, MG).

É o quinto de oito irmãos; os pais, agricultores, não têm instrução formal. Zaqueu de Melo e os irmãos entram e saem de escolas várias vezes, devido às constantes dificuldades econômicas da família; no caso de Zaqueu de Melo, também por doenças. Mas as sucessivas migrações e dificuldades da grande família assim se punham: os irmãos devem se revezar ao estudar nos colégios pagos e distantes de casa.

Zaqueu termina os estudos no Ginásio Municipal de Lavras (MG), o atual Instituto Presbiteriano Gammon, obtendo o grau de bacharel em Ciências e Letras. Estudaria também na Faculdade Teológica de Campinas (SP), atual Seminário Presbiteriano do Sul (MELO, 2014, p. 09-21). Tem, portanto, formação também em Teologia.

Morando em São João da Boa Vista, torna-se pastor e ministro da igreja presbiteriana por cinco anos, entre 1940 e 1944, ajudando a construir o templo local. Também ensina filosofia, grego e inglês no Ginásio Estadual da cidade.
Com dois filhos pequenos, frutos do casamento com Isaura Maura de Melo, chega ao norte do Paraná em 1944 (MELO, 2014, p. 139). Por onde passa, atua na área educacional, inclusive trazendo professores capacitados a Londrina, quando ela não dispunha de tais profissionais. Ensina português e dirige o Colégio Estadual Vicente Rijo, entre 1946 e 1951; entre 1945 e 1975, dirige o Instituto Filadélfia de Londrina (MELO, 2014, p. 145-6).

Ajuda a fundar, com outras lideranças religiosas protestantes, o Colégio Londrinense e o Instituto Filadélfia de Londrina, primeira entidade com cursos superiores na cidade, em 1956. Ambas seriam embriões da atual Universidade Filadélfia de Londrina, a UNIFIL (BERTAN, 1990, p. 42-3). De certa forma, a estrutura da religião o auxilia: entre as décadas de 1920 a 1960, as denominações cristãs em geral ajudam a construir instituições educacionais, dentro dos debates nacionais a respeito de quem comandaria o ensino no país, se o Estado (o poder público) ou organizações cristãs (entidades privadas). Zaqueu de Melo mediou entre os lados.

De outro lado, ele também ajuda a criar a Faculdade Estadual de Filosofia, embrião da futura UEL ${ }^{9}$. Mas a conquista desses cursos também é fruto de sua breve participação na política. Zaqueu de Melo elege-se deputado estadual pelo Partido Social Progressista (PSP) para os períodos de 1955-58 e 1959-63 (renunciaria em 1962), tendo as vitórias creditadas como oriundas de suas 
atividades, nos anos 1950, na Folha de Londrina, veículo conhecido pelas ligações com o poder executivo local (MARSON, 2005, p 94).

Também batalhou para instituir a Sociedade Evangélica Beneficente (responsável pelo surgimento, posteriormente, do Hospital Evangélico), a União Fraternal Brasileira e o Serviço de Obras Sociais, entidades que faziam caridade em geral, ajudavam migrantes recém-chegados, desabrigados etc. (MELO, 2014, p 107).

Zaqueu de Melo demonstra preocupações com o desenvolvimento cultural e artístico da cidade: recém-chegado, batalha para a expansão da Biblioteca Pública Municipal e para a fundação das (efêmeras) Sociedade Londrinense de Cultura Artística e Sociedade de Cultura Artística de Londrina, entidades promotoras e apoiadoras de eventos musicais. Assim, por iniciativa sua, nasce o Conservatório Musical Filadélfia, mantido por quase duas décadas no Colégio Londrinense (CAMPOS, 2009). Por tais motivos, é nomeado patrono da cadeira número 6 da Academia de Letras, Ciências e Artes de Londrina (MELO, 2014, p. 21). Também recebe o título de cidadão honorário e o mais importante teatro de Londrina foi homenageado com seu nome (MELO, 2014)

Segundo sua biógrafa e filha, Carmen de Melo (MELO, 2014), Zaqueu sempre gostou de genealogias; ele afirmava ter cerca de duas centenas de ancestrais, cujas famílias paterna (Pereira de Melo e Souza Caldas) e materna (Mendonça e Morato) teriam vindo de Portugal no início século XVIII e se estabelecido em Minas Gerais (MELO, 2014, p. 132-9).

Zaqueu de Melo escreveu cerca de 90 artigos, ainda antes de viver em Londrina, para jornais do interior dos estados de Minas Gerais e São Paulo, nas localidades onde morara ou próximas. Já na Folha de Londrina, entre as décadas de 1950 a 1970, seriam mais de 50 (MELO, 2014, p. 33-38). Finalmente, além dos muitos textos e artigos esparsos em jornais, registram-se como obras os livros Crônicas e ensaios religiosos (1953) e ... E eles não puderam... (1965).

\section{Marinósio Trigueiros Filho}

Outro integrante de nossa pesquisa é Marinósio Trigueiros Filho (músico, cantor, compositor e jornalista), nascido em Salvador (BA), em 1914, e falecido em 1990, em Londrina.

É filho de Marinósio Trigueiros, nascido em Salvador (BA); sua mãe é Jovita do Nascimento, nascida e criada em Itapuã (perto de Salvador), isolada e tradicional comunidade de pescadores, oriunda, supostamente, de quilombo do século XVIII. O casal teve seis filhos. 
Do pai, Marinósio Trigueiros Filho herda o nome e a paixão pela música; o progenitor a ensinava e era maestro em bandas que tocavam regularmente num hospital psiquiátrico da capital baiana, para animar os pacientes, segundo o historiado Felipe Melhado (2014, p. 116).

$\mathrm{Na}$ adolescência, Marinósio Trigueiros Filho ensaia os primeiros versos. Também trabalha nas áreas da comunicação (jornalismo) e nas artes cênicas (atuando e cantando em teatros de revista). Gosta de samba, de compor e da boemia. Nessa vida errante e boêmia, passa alguns meses preso por estelionato, em 1937. O rapaz usa as artes da dissimulação e da mentira para entrar e sair de embaraçosas situações amorosas, financeiras, de trabalho etc., cujas descrições abundam no estudo de Melhado (2014). As comprovações são documentos do próprio Marinósio Trigueiros Filho e de sua família.

Antes de se estabelecer em Londrina, ele se apresenta com o pomposo nome de "Professor Marinósio", um pesquisador do folclore nacional, e que atua com instrumentos musicais do folclore nacional típicos, como agogô, berimbau, ganzá etc. (MELHADO, 2014). Ainda no final dos anos 1930, acompanhado de grupos vocais, realiza apresentações de samba (alguns de sua autoria) e peças musicais, em cassinos do Brasil e Uruguai. Seu mundo é o vaudeville e uma vida mambembe.
As viagens redundam em aporte de conhecimentos com os quais chega a montar um grupo musical próprio, com ritmos folclóricos brasileiros, típicos do período nacionalista e populista solicitado pelo Estado Novo getulista (MELHADO, 2014; PEDREIRO, 2013). Ele toca, compõe e canta sambas, choros, marchas, afoxés etc. Essas experiências teriam sido a fonte para a composição da "marchinha" de carnaval Cachaça, nacionalmente conhecida, composta em 1946 e gravada poucos anos depois (PEDREIRO, 2013; FRANCOVIG, 2005). Contudo, somente nos anos 1990 ele seria reconhecido como o principal autor da canção, cuja autoria foi dividida com outros três compositores (LUPORINI, 2011).

A respeito de seus relacionamentos amorosos, uma de suas grandes companheiras, na década de 1960, é a importante cafetina londrinense Maria Plascidina Prens (a "Cidica"), de quem se tornaria sócio. Outra importante companheira, num relacionamento que duraria quase duas décadas, foi Dulce de Almeida, vedete do teatro de revista da então capital federal, o Rio de Janeiro. Teve com ela um filho, Marinósio Trigueiros Neto. Ficaram juntos até a morte dela, em 1958. Nos anos 1960, ele também se uniria a outra jovem, Vinie Moratore, com quem teria tido outros três filhos (MELHADO, 2014)

Marinosio Trigueiros Filho chega a Londrina em 1944, muito pela fama da riqueza que corria no local e também como 
${ }^{10}$ Segundo o historiador Paulo de Tarso Gonçalvez, na época “(...) existiram muitos outros jornais na cidade, entre os quais: "Folha de Londrina", diretor Jamil Elias; "O Furo", diretor Dicesar Plaisant Filho; "Semanário Esportivo", diretores Abrahão Andery e Dicesar Plaisant; "Correio Paranaense", diretores Pedro Corcio Parre " Gazeta do Norte", diretores Vitor Bosso e Francisco Tuma; "O Combate", diretor Marinósio Trigueiros Filho; "Folha do Povo", diretores Osmario Batisaco (sic) e Danie Gonçalves; "A Voz do Campo", diretor Hilário Correa; "O Repórter", diretor Renato Melito; "A Voz do Norte", diretor Floriano Mendes; "Realizações Brasileiras", revista de Gustavo Branco F. Mioni" (GONÇALVEZ, 2008).

${ }^{11}$ Segundo o historiador Tony Hara: "Esses jornalistas eram sensíveis à ambiguidade da vida social. Tinham o gosto pela vida mundana e, simultaneamente, eram representantes e defensores da vida ordeira, regrada, trabalhadora que fazia parte do repertório do cidadão que fazia parte do repertório Debada cidade]. (...) Debandando de lá para cá, transitando com desenvoltura da margem para centro e do centro para a margem, (...) gravitavam em torno de duas realidades paralelas e conflitantes. Eles conheceram o beabá da marginália, ao mesmo tempo em que circularam entre as pessoas que faziam parte das altas rodas e esferas do poder, que também tinham seus truques e manhas para permaneceram na posição privilegiada em que se encosção (apud MELHADO, 2014, p. 208-9). correspondente do jornal O Dia, de Salvador. De início, também atua artisticamente nos cabarés e prostíbulos da cidade, como gostava. Já na vida profissional da imprensa, alia-se, em 1947, a um grupo político local para fundar o jornal $\mathrm{O}$ Combate $(\text { PEDREIRO, 2013) })^{10}$. Ao comentar a boêmia literária de seu tempo, Marinósio Trigueiros Filho afirma, acidamente, que muito embora os jornalistas sobrevivessem com pouco dinheiro, viviam "rodeados por ricos de todos os lados (...) que (...) gostavam de falar da opulência da cidade”, quando a riqueza do café era notícia por todo o país (TRIGUEIROS FILHO; TRIGUEIROS NETO, 1991, p. 65).

Vida noturna, boemia, música etc. juntam-se ao universo de profissionais da imprensa, políticos, empresários, policiais, delegados, entre outros ${ }^{11}$. Isso dá intimidade a Marinósio Trigueiros Filho para saber com quem poderia se envolver, seja apoiando, seja criticando. Assim, foram intensos seus apoios a prefeito e a governador (comumente, patrões, donos ou financiadores dos jornais onde atuava). Vender negociatas e opiniões era seu negócio, com o colunismo social interessado (MELHADO, 2014, p. 179). Ele escreve em O Dia, Última Hora, O Combate etc., alguns efêmeros, que ele mesmo fundaria, na década de 1950 .

Após o início do regime militar e consequente perda de financiadores de O Combate (como Moisés Lupion e Barros
Munhoz, por não serem apoiadores de primeira hora do novo regime), Marinósio Trigueiros Filho modifica o veículo: agora não se centra tanto em política, mas em crimes, sexo e violência, para popularizá-lo, conseguir vender mais e sobreviver. Decide fechá-lo em 1966 (MELHADO, 2014, p. 275-82), e retorna à cidade natal, Salvador, para voltar a Londrina somente quatro anos depois.

No retorno a Londrina, no início da década de 1970, ele obtém sua própria editora local, escrevendo agora livros e textos de interesse próprio ou a pedidos, como o panfleto promocional Londrina 70 - Um ano da administração Dalton Paranaguá, entre outras publicações (MELHADO, 2014, p. 283-4). Em 1972, Marinosio Trigueiros Filho publica o primeiro livro, Gente de Londrina - enciclopédia biográfica, compilação de 500 biografiasverbetes sobre personalidades da cidade. Em 1973, vem a lume Crimes que abalaram Londrina, com histórias de processos criminais do fórum da cidade, por sua editora. Em 1978, do mesmo modo, lança o livro de poemas Do outro lado da rua. Em 1979, viria Dos porões da delegacia de polícia.

Em 1982, viria a obra coletiva Vozes: poemas. Em 1983, surge A lei dos "homens da lei", em que explora novamente aspectos problemáticos da polícia e das prisões, tendo matérias de jornais como principais fontes. Em 1989, publica Meus últimos poemas (até agora), dedicando textos aos filhos e netos.

Dossiê Arte do Carnaval

Arquivos do CMD, Volume 6, N.1. Jul/Dez 2017 
Após sua morte, é lançado seu livro último, História da Imprensa de Londrina (do baú do jornalista), no ano de 1991, que ele iniciara dez anos, e que foi finalizada pelo filho, Marinósio Neto, narrando fatos que o autor recolheu e viveu enquanto foi jornalista em Londrina. Aliás, a maior parte das obras de Marinósio Trigueiros Filho é produto de seu trabalho de imprensa na área criminal. O livro Dos porões da delegacia de polícia, por exemplo, é composto de crônicas sobre crimes, torturas e violências em geral, todas, segundo o autor, cometidas pela polícia. O autor se baseia em relato de que foi testemunha ou dos quais ouviu em forma de boatos. O livro se pretende uma denúncia, quase um libelo, por parte de ladrões, prostitutas, mendigos, enfim, os elementos sociais marginais que seriam "contra a maré vitoriosa" da cidade que cresce e traz riquezas a muitos (PEDREIRO, 2013).

Atuando na área cultural da cidade, é importante ressaltar que Marinósio Trigueiros Filho, em 1955, ajuda a fundar a Associação Norte Paranaense de Imprensa (ANPI). A entidade cria uma efêmera revista, em 1963, publicando poemas e contos de autores locais. O órgão serve como um sindicato de jornalistas, e uma das poucas entidades da sociedade local a dar espaço à cultura de alguma forma.

A luta de Marinósio Trigueiros Filho e outros por mais apoio do poder público municipal pela cultura redunda na criação do I Mural da Poesia, exposição de peças de autores locais, que ocorreria em 1976. O evento chama a atenção das autoridades e motiva similares em prefeituras vizinhas. E, entre 1976 e 1980, o escritor ajuda a organizar mais cinco desses murais na cidade. Foi uma grande vitória da parte dele (FRANCOVIG, 2005).

O mural também seria a semente da futura Academia de Letras, Ciências e Artes de Londrina, entidade que Marinósio Trigueiros Filho e outros letrados locais ajudam a fundar, em 1978. Ela reúne políticos, jornalistas, escritores, advogados, professores, diletantes e letrados em geral

Em 1980, Marinósio Trigueiros Filho funda outra entidade, o Centro Cultural Brasileiro de Pesquisas e Estudos Sociais, entidade que organiza eventos laudatórios, promove homenagens públicas, inventa e comercializa comendas e condecorações (Cavaleiro do Centro Cultural, Medalha Jubileu do Ouro Verde, Prêmio Destaque Mulher) e que edita a maioria das publicações organizadas pelo escritor, como a de seu livro de poemas, Vozes, de 1982.

Pela entidade, ele publica, em 1985, Duas filhas malditas, texto autobiográfico abordando seu relacionamento com "Cidica" e a polêmica e indiscreta disputa jurídica entre o autor e as filhas da amante pela herança desta. O jornalista vence o imbróglio e transforma a história em romance (MELHADO, 2014, p. 287). 
12 Eis um discurso do então presidente da Academia de Letras, Ciências e Artes de Londrina sobre João Soares Caldas: "Foi por um ato de amor que o saudoso Presidente Dr. João Soares Caldas, no dia $1^{\circ}$ de Setembro de 1978, pronunciou, no convite para a instalação de uma instituição em favor da cultura, que se (actura, que se cestinado a "marcar mais uma efeméride significativa a vida londrinense [porque fazia tomarem assento os participantes] efetivos da Academia de Letras, Ciências e Artes de Londrina, que vão representar os valores desta região". E foi isso o que, de fato, aconteceu: Uma trajetória ininterrupta (...), uma existência evolutiva, sempre sob o comando firme do imortal Presidente, com sabedoria, vicão de futuro, senso comprodoria, visão de futuro, senso de compromisso com valores humanos acima de tudo, paixão pela cidade de Londrina e região. Resulta, para todos nós, a eloquente certeza de que os ideais que ele buscava estão corporificados nessa comenda, e os presentes a este ato sentem orgulho de terem convivido com tão inspiradora figura" (PROTA, 2017)
Nada convencional, mas típico do estilo de Marinósio Trigueiros Filho: indiscrição, autoconsagração e publicações do próprio bolso.

Esta, aliás, é uma das faces da controvertida trajetória de pessoa empenhada em conflitos e embates em geral; de modo particular, nos que ocorreram em Londrina. É também personalidade perpassada por "ambiguidades morais": suas relações simultâneas com a elite político-financeira e com "marginalizados" da cidade; sua intimidade com o meretrício, sucedida de virulentos ataques em jornal a tal negócio; e sua pena de aluguel, apesar de tal elemento ser corriqueiro na prática jornalística de então (MELHADO, 2014, p. 107). Tudo isso se interpõe para mostrá-lo como personalidade cambiante, que negocia seus parcos capitais na luta pelo desejo de se locupletar e "vencer" intelectualmente na cidade.

\section{João Soares Caldas}

João Soares Caldas nasce em Jaboatão (SE), em 1925, e vem a falecer em Londrina, em 2013. Supostamente de família de altas posições sociais em seu estado natal, o letrado forma-se em Direito na então Universidade do Brasil, no Rio de Janeiro, em 1952. Atuaria por mais de cinco décadas em Londrina, boa parte do período como procurador jurídico da Prefeitura. Na cidade, também preside a Associação dos Advogados de Londrina, o Elos Clube de Londrina, o Rotary Club da cidade e a Sociedade Internacional de Criminologia.

Na Prefeitura, dirige a Autarquia Municipal de Esportes e Turismo e se torna secretário municipal da Comissão Especial para Implantação dos Serviços Automáticos de Londrina (BARH, 2017; ICAB, 2013).

Tendo grande apreço pela literatura (BARH, 2017), atua como um dos principais fundadores da Academia de Letras, Ciências e Artes de Londrina ${ }^{12}$, em 1978, sendo seu presidente por mais de três décadas, bem como editor de Almenara, o periódico da entidade (BARH, 2017). Também é um dos criadores do Centro Nordestino do Paraná. É, finalmente, autor dos livros A vida e o todo (poemas) (s/d); 88 oferendas (poemas) (s/d) e Fragmentos (poemas) (2000; 2006).

\section{Edison Maschio}

O próximo nome é o de Edison Maschio, jornalista nascido em Assis (SP), em 1934, e que chega a Londrina em 1938. Na cidade, trabalharia, desde 1953, nos jornais Gazeta do Norte, Paraná-Norte e O diário (fundado por ele em 1969). É o primeiro autor com obra de algum destaque e razoável tiragem, o Escândalos da província, de 1959.

Dossiê Arte do Carnaval

Arquivos do CMD, Volume 6, N.1. Jul/Dez 2017 
O que há de literatura em Londrina, desde sua fundação, são apenas "acidentes literários" (FRANCOVIG, 2005, p. 29), mas este não é o caso do referido livro. Custeado pelo próprio autor, é apreendido e tem as cópias incineradas; mas seus 2000 exemplares são vendidos em uma semana, fato raro. Trata-se de romance de sátira social, com personagens envolvidas em traições amorosas escandalosas, prostituição, corrupção etc. Os nomes fictícios não escondem a fama das histórias de pessoas conhecidas na cidade, e tomadas como "casos abafados". Devido à repercussão negativa, o autor se ausenta da cidade por algum tempo, refugiando-se na capital paulista. Assim, o sucesso da obra ficou registrado relançada em 2011, foi motivo de trabalhos acadêmicos na UEL, bem como de lembranças e menções na imprensa contemporânea (GONÇALVEZ, 2008; FRANCOVIG, 2005).

Décadas após esse livro, Edison Maschio publica outras duas obras de mesmo teor, ou seja, jornalísticas e ácidas em relação à sociedade local e a seus costumes e visões de mundo, quais sejam, Raposas do asfalto (1984) e Histórias ocultas (2010).

Do que obtivemos, podemos entender que Edison Maschio é um jornalista típico da época, atuante em veículos de comunicação locais; gosta de escrever contra costumes, a moralidade da época e os poderosos de então. Sempre um outsider; na velhice, é motivo de apupos por movimentos da cena cultura mambembe e "esquerdista" da cidade. Hoje, está aposentado

\section{Nitis jacon}

Em sequência, temos Nitis Jacon de Araújo Moreira, atriz, produtora, diretora teatral e médica psiquiátrica, nascida em Lençóis Paulista (SP), em 1935. É filha de imigrantes, sendo o pai espanhol e mãe italiana, e ambos muito pobres. A pequena lê muito quando criança, gosta de Monteiro Lobato, de encenar pequenas peças e recitar poesias entre amigos (AMARAL, 2016). Com a vida complicada pelo fato de a família ser oriunda de estratos sociais inferiores (NICASTRO, 2016), ela frequenta o Grupo Escolar público da cidade, mas, por tirar boas notas nele, o diretor de um colégio de freiras particular consegue para a menina uma bolsa de estudos (ainda que ela tenha de ajudar na limpeza do local, como retribuição)

Muda-se para Curitiba em meados dos anos 1940, nela realizando os ensinos fundamental e médio, bem como inicia a graduação em Medicina na Universidade Federal do Paraná (UFPR). Contudo, interrompe os estudos para casar-se com o colega de curso, Abelardo Araújo; quando este se forma, ambos se mudam para a cidade natal dele, Arapongas (PR), onde nascem os três filhos do casal. Ela somente terminaria essa graduação no início da década de 1980, na UEL.

Sendo amante das artes em geral e do teatro em particular (na adolescência já fazia radionovelas), torna-se figura proeminente 
dessas áreas, principalmente na cidade de Londrina, local onde ela atua a partir do início década da década de 1970.

Nessa cidade, durante a decretação do Ato Institucional $n^{\circ}$ 5, em 1968, começa a ser esboçado o futuro FILO. Nitis Jacon relembra em entrevista que “(...) por saberem da minha atuação no teatro em Curitiba e por ter recebido prêmios e me destacado nessa área (...), fui convidada por esses estudantes para participar e apoiálos no Festival" (NICASTRO, 2016). No evento, ela marca presença por mais de quatro décadas, em termos políticos e institucionais, para sua manutenção e ampliação. Essa sua atuação tornaria o evento um dos mais longevos do país.

Nitis Jacon dá força ao setor do teatro, montando grupos que vencem festivais e recebem diversos prêmios e troféus, ao longo de décadas, em níveis locais, nacionais e internacionais. Já na edição de 1969, ela dirige Arena conta Zumbi (de Augusto Boal e Gianfrancesco Guarnieri), mas a peça é proibida pela censura, sendo permitida apenas no ano seguinte (MARINHO, 2005, p. 44). Mais tarde, em 1972, surge o Grupo NUCLEO, também com direção de Nitis Jacon, integrado por alunos e ex-alunos da $U E L$, e cujos textos questionam a realidade do país à época. Em 1978, ela dirige, entre outros, o Projeto Experimental de Teatro Universitário (PROTEU), formado por amadores, mas com o intuito de preparar melhor tecnicamente atores e diretores, e que seria importante no cenário cultural brasileiro das décadas seguintes. Já na vizinha cidade de Arapongas, ela funda o Grupo de Teatro da Faculdade de Filosofia de Araponga (GRUTA).

Aos poucos, a organização do festival, ainda amadora em mãos de estudantes e de suas entidades, vai trocando de direção. Em 1971, Nitis Jacon é convidada a assumir o setor de cultura da $U E L$, pois a instituição demonstra interesse em encampar o festival, pela necessidade de realizar trabalhos de extensão à comunidade no âmbito cultural (MARINHO, 2005, p. 53). Integrante da comissão de música do Festival, a artista adentra a área de cultura da instituição, tornando-se também funcionária da universidade. Assim, a partir de 1972, a UEL, com Nitis Jacon e o então Setor de Teatro da Coordenadoria de Assuntos Culturais (CAC), assume, definitivamente, a organização do festival. A partir de agora, a organização enfatiza desenvolver “(...) atividades que contribuam para descentralizar informações e agir no âmbito de formação dos participantes". Ou seja, a edição assume promover o teatro amador e abrir espaço para a prática (MARINHO, 2005, p. 58).

Entre 1974 e 1975, o trabalho de Nitis Jacon na UEL é interrompido: ela se licencia da universidade à Inglaterra com o marido, para ele realizar estágio profissional. Foram ao exterior para que ele não fosse preso, pois ambos eram considerados subversivos que auxiliavam outros perseguidos. Mas, em novo local, a artista toma contato com atuantes de diversas formas de arte, e o faz por boa parte do continente europeu. 
Ao voltarem, o marido é temporariamente preso; enquanto isso, Nitis Jacon retorna à UEL, procurando dar sequência a seus grupos de teatro e ao festival. Em razão da função que ocupa, é obrigada a tratar liberações de peças de teatro com a polícia e censores do governo (MARINHO, 2005, p. 144).

Doravante, Nitis Jacon empreende outras viagens pelo mundo, ampliando os contatos e convidando grupos latinoamericanos, europeus, africanos etc., a participar das edições do festival. Assim, o evento torna-se Festival Latino-Americano de Teatro; finalmente, a partir de 1990, o FILO (NICASTRO, 2016) encampando grupos de todo o planeta. Esses contatos e viagens pela Europa e América Latina servem para a artista se relacionar com grupos artísticos e de teatro.

Dessa forma, ela se aprofunda na organização e direção de eventos dessa natureza. Isso adensa sua experiência na área, a qual se inicia na década de 1950, quando Nitis Jacon faz teatro em Curitiba, chegando a ganhar prêmios nacionais por suas atuações como atriz; e se adensa por ela transitar com facilidade no eixo Rio-São Paulo, mantendo contatos com pessoas importantes do meio, como Paschoal Carlos Magno, Gianfrancesco Guarnieri, João das Neves, Chico Buarque etc. (MARINHO, 2005, p. 152; 163).

A vida no comando do festival, contudo, não era um mar de rosas para a artista: representando a universidade, ela tem de mediar entreveros entre grupos defensores de peças "engajadas" e os que preferem as "alienadas", neutras ou não politizadas. Isso faz com que ela se afaste por dois anos da organização do evento (MARINHO, 2005, p.70). Em 1982, seu mandato é extinto à sua revelia durante uma reunião da Comissão Estadual de Artes Cênicas (CEAC), por questões políticas e, segundo ela, por “patrulhamento ideológico" (MARINHO, 2005, p. 84). Aliás, Nitis Jacon critica constantemente a falta de apoio dos poderes públicos, afirmando não existir "política cultural por parte dos governantes, a não ser a de arrecadar votos" (MARINHO, 2005, p. 139). Nesse sentido, apenas a partir de 1988, o Festival de Londrina passa a ser custeado por patrocinadores, o que permite uma organização mais profissional; com isso, ele se consolida perante o público, a imprensa e a cena cultural nacional (MARINHO, 2005, p. 163). O festival obtém críticas positivas em grandes jornais nacionais, como Folha de S. Paulo e $O$ Estado de S. Paulo, com elogios à capacidade de organizacional de Nitis Jacon.

Houve também críticas negativas, mas o festival e sua organizadora apareceram para o país (MARINHO, 2005, p. 102104). A chegada ao status de principal mostra do país é destacada por críticos e jornalistas nesses primeiros anos de sua transformação em FILO. Ganhando reconhecimento internacional no início da década de 1990 da UNESCO, ele se somaria ao patrimônio cultura da cidade, do Paraná e do país (LEITE, 2012, p. 57). Já em meados da década de 1980, com a transição democrática, o teatro e as outras formas de arte começam a passar por transformações; o cenário em Londrina determina a busca de 
${ }^{13} \mathrm{Em}$ entrevista, Nitis Jacon afirma: "O período de transição foi uma crise de linguagem para $o$ teatro. Durante a ditadura havíamos desenvolvido técnicas e linguagem metafórica para uma comunicação com o público sem os riscos da censura. (. ) com a abertura (..), os livros, músicas e filmes que haviam sido livros, músicas e filmes que haviam sido proibidos ressurgiram e nossa linguagem se tornara inútil. $\mathrm{O}$ teatro havia sido uma das principais frentes de resistência pela comunicação direta com o público, estava aí a sua força" (MARINHO, 2005, p 155-6).

${ }^{14} \mathrm{Nitis}$ Jacon realizou um trabalho para a revista Cláudia, “(...) projeto que escolhia uma mulher batalhadora. Gostei muito dessa dessa atividade e do contato com a entrevista (NICASTRO, 2016). novas estéticas para o festival (que ainda tem essa forma artística como central) ${ }^{13}$.

No início dos anos 1990, Nitis Jacon auxilia na criação do curso de Artes Cênicas da UEL; entre 1994 e 1998, atua como vice-reitora da instituição; em 2000, ainda como diretora artística do festival, torna-se membro do Conselho Assessor do Patronato do Festival Ibero-americano de Teatro (FIT), de Cádiz, na Espanha, o que lhe traz mais legitimidade e possibilidades de trazer representações artísticas internacionais para Londrina (MARINHO, 2005, p. 137). Em 2002, o governador convida-a para a diretoria do importante Teatro Guaíra, por três anos; torna-se presidente da Fundação Guaíra, em Curitiba; ainda nesse mesmo ano de 2002, é candidata derrotada ao Senado, pelo Partido da Social Democracia Brasileira $(P S D B)$ do Paraná.

Nitis Jacon finaliza suas atividades na UEL em 2003. Logo após, torna-se diretora clínica do Hospital de Arapongas, mas continua ligada ao FILO, dando-lhe consultoria e sendo sua presidente de honra ${ }^{14}$. Viúva e aposentada, mora em Arapongas; dos três filhos, um trabalha com dança; outro é fazendeiro; e a terceira, antropóloga (NICASTRO, 2016).

A graduação em Medicina, atropelada, seria finalizada em meados dos anos 1980, na própria UEL, onde também faria residência em Psiquiatria, ao mesmo tempo em que era responsável pela parte cultural da universidade (NICASTRO, 2016). Com isso, podemos entender que ela conclui "à força" o curso de Medicina, com foco em Psiquiatria, o que mostra mais a vontade de ser burocrata do que de se realizar na profissão. Também sua militância é gangorra, com a artista se bandeando para vários lados ao longo das décadas, acompanhando as modificações na balança de poder (de "comunista" a "tucana").

Além de trabalhos técnicos referentes à burocracia universitária, registram-se, entre suas obras, o Memória e Recordação - Festival Internacional de Londrina, 40 anos (2010), de teor memorialístico, editado e patrocinado por ela própria e pela empresa Petrobras, 2010.

\section{Delio Cesar}

Finalmente, temos Delio Nunes Cesar, jornalista, empreendedor cultural, militante partidário e político, nascido em Alegre (ES), em 1939, e falecido em Londrina em 2015. Casado com Avani Cesar, teve três filhos. Sétimo de nove irmãos, é o único capixaba entre mineiros e o único a trazer o sobrenome materno Nunes (OSTI, 2013). Em seu primeiro ano de vida, a família muda-se da cidade natal para Alto Jequitibá (MG). Nela, Delio Cesar estuda no colégio evangélico (presbiteriano) local, bem como inicia-se no teatro e na vida cultural. 
Aos quatorze anos, acompanha novamente a família, agora para Londrina. O primeiro emprego é na Caixa Econômica Federal depois, no comércio do centro da cidade. Pratica futebol de salão, atuando no selecionado municipal; torna-se membro da União da Mocidade Presbiteriana (UMP), fazendo teatro e jornal na igreja também participa de programas de calouros de rádio (OSTI, 2013 GOUVEA, 2015).

Aos dezenove anos, muda-se para a cidade de São Paulo, onde se emprega como funcionário de banco privado (o extinto COMIND); entra no curso de Jornalismo da Faculdades Cásper Líbero, mas o abandona no primeiro ano, trocando-o pela cena cultural, pela política e pela boêmia da cidade. Adentra a militância política no Partido Comunista Brasileiro (PCB), editando o jornal clandestino da organização; também participa do movimento estudantil nesse início dos anos 1960

Inicia-se na militância da juventude comunista de São Paulo ainda no curso de Jornalismo, atuando no jornal Terra Livre, semanário do movimento camponês braço do PCB. Também passa por grupos teatrais de diversas outras organizações políticas esquerdistas (FERNANDES, 2012, p. 134). No ARENA, Oficina e Teatro Brasileiro de Comédia (TBC), conhece importantes dramaturgos e artistas engajados, como Flavio Migliaccio, Gianfrancesco Guarnieri e Juca de Oliveira (MARINHO, 2005, $18)$.

Dossiê Arte do Carnaval

Arquivos do CMD, Volume 6, N.1. Jul/Dez 2017
Em entrevista, Delio Cesar afirma ter tido educação social e escolar infantil presbiteriana e anticomunista; que se convertera a essa ideologia quando adolescente, após ter assistido palestra do líder Luiz Carlos Prestes em São Paulo, mas que já discutia política no banco onde trabalhava na capital paulista, no início dos anos 1960 (FERNANDES, 2012, p. 135); também tinha, nessa época, simpatia pelo ditador de Cuba, Fidel Castro, e seu companheiro de militância, Ernesto Che Guevara (MARINHO, 2005, p. 17).

Delio Cesar volta a Londrina em 1961 para dirigir a redação da sucursal local do carioca Última Hora, jornal populista e janguista, então recém-inaugurado na cidade (FERNANDES, 2012, p. 134). Tudo isso até 1964, pois, com o golpe militar, o jornal em Londrina é fechado. Delio Cesar consegue se transferir para a Folha de Londrina. Ainda nesse ano de 1964, matricula-se na então Faculdade Estadual de Direito local, cujo curso, desta vez, terminaria.

No final da década de 1960, sob a influência de teatros e festivais da canção militantes existentes por todo o país, Delio Cesar pensa em algo similar para Londrina. Antes disso, a única atividade teatral que a cidade presencia é o Grupo Permanente de Teatro (GPT), criado em 1956 por, entre outros, o dramaturgo e ator paulistano Roberto Koln, e que duraria até 1964. Inspirado no paulistano Teatro Brasileiro de Comédia $(T B C)$, inicialmente, tinha 
${ }^{15}$ Segundo o pesquisador Marinho (2005, p. 38-43), "uma das grandes conquistas, ainda, foi o convite feito pelo prefeito eleito naquele ano, Dalton Paranaguá, para Delio Cesar assumir a Secretaria de Cultura (...). Ele recusou, porém Cupresentou a proposta para ser discutida apresentou a proposta para ser discutida no Centro Universitário de Cultura Artistica (CUCA), presidido por Delio Cesar. Os estudantes indicaram o arquiteto Abinoan Siqueira". como membros e plateia a elite da cidade, uma estratégia para obter prestígio perante a sociedade (LEITE, 2012, p. 55-6).

Mas agora, com o bom número de estudantes e de cursos na cidade, vinha a calhar a nova empreitada (FERNANDES, 2012, p. 213-4). Assim, ligado na efervescência social, e aproveitando as suas experiências acumuladas nas áreas cultural e religiosa, bem como o fato de ser ainda estudante (de Direito), Delio Cesar organiza, com um amigo esportista, os Jogos Universitários de Londrina. Logo após, reúne mais amigos e cria, em 1968, o Festival Universitário de Londrina, com o teatro como carro-chefe, sendo que cada curso superior da cidade apresentaria uma peça; também haveria concursos e mostras de artes plásticas, contos, poesias, jograis, música, pintura, escultura etc. (LEITE, 2012; OSTI, 2013). Bem-sucedido, o evento obteve apoio da imprensa (rádios, televisões e jornais). Com esse sucesso, ele se transformaria no atual FILO (OSTI, 2013; GOUVEA, 2015) ${ }^{15}$.

De outro lado, é bom lembrar que esses eventos e festivais são típicos de movimentos esquerdistas para se infiltrar em meios artísticos e educacionais, como tática para se inserir na faixa etária e na produção cultural, para propagar seu ideário; para isso, a instrumentalização de estudantes, artistas e suas obras se fazem necessárias. Estes, por sua vez, instrumentalizariam a cultura popular e folclórica. Tudo isso com vistas a "educar" a população contra o regime militar e o sistema capitalista. Artistas e intelectuais muito atuaram nesse sentido, usando seus saberes e militando sutilmente em partidos e organizações esquerdistas, ou na grande imprensa, nas universidades, igrejas etc

Delio Cesar representa isso em Londrina, mesmo porque foi eleito vereador por Londrina em 1968 pelo Movimento Democrático Brasileiro (MDB), que ajuda a criar; essa vitória ele devota à sua atuação pelo festival (MARINHO, 2005, p. 37). O mandato vai de 1969-1973. Além de vereador, seria vice-prefeito da cidade no período de 1983-88, agora pelo Partido do Movimento Democrático Brasileiro (PMDB).

Outra área onde trabalharia é a de marketing político (OSTI, 2013; GOUVEA, 2015); mas, dos anos 1960 aos anos 1990, também atuaria na área empresarial da imprensa escrita e televisiva. Funda os jornais locais Diário de Londrina, Panorama e Jornal de Londrina. No início do século XXI, atuaria na então recente internet. Em 2001, publica A primavera de Londrina, coletânea de sua coluna diária da internet, abordando a política local.

Em 2013, recebe o título de cidadão honorário pela câmara municipal local (OSTI, 2013) e homenagem de ex-governador do Paraná. Vemos também que Delio Cesar faz dois cursos superiores (concluindo um deles): é, portanto, militante político (a serviço do PCB) na área universitária. Apesar de vereador e vice-prefeito, era secundarizado na vida política. Registra-se, como obra publicada, 
A primavera de Londrina: o despertar de uma cidade contra a corrupção (crônicas políticas) (2001).

\section{$* * *$}

Vejamos, a seguir, correlações e interpretações conjuntas e sistemáticas entre todos os pesquisados.

\section{Capitais e investimentos}

Antes de tudo, sobre as fontes obtidas, é importante lembrar que são construções e reconstruções interessadas de vidas, feitas por admiradores, parentes, amigos, editores, chefes ou instituições constituem apologias, hagiografias, reverências ou "canonizações" dos letrados analisados. Por espontâneas, expõem elogios e exageros em fatos irrelevantes de suas vidas, para torná-los importantes ou heroicos. Também eufemizam e abafam fatos e situações obscuras ou embaraçosas. Eis as devidas reservas e relativizações, motivo pelo qual tais informações não foram totalmente tomadas pelo "valor de face".

A partir da verificação das origens sociais dos intelectuais estudados, podemos entender que a maioria teve atuação profissional eficiente (ao menos para os limites da cidade) devido a sólidas bases escolares e culturais. Sem posição confortável em patrimônios familiares, restava-lhes "valorizarem-se" com investimentos escolares (diplomas e cultura geral), obtidos em bons colégios, onde também assimilam valores morais e religiosos, e em instituições de nível superior. Tal questão se insere no habitus da valorização educacional formal, característico de famílias humildes (mas, não só), das quais a imensa maioria desses intelectuais se origina.

A reconstituição das trajetórias de vidas também fez aparecer posicionamentos que funcionam bem devido ao nível competente desses letrados em manejar seus capitais sociais (ou de relacionamento) ao ter de interagir com grupos de poder em Londrina. Esta habilidade se relaciona às estratégias do habitus de suas famílias, de migrantes esforçados, com a pretensão de ascensão social, para si e seus filhos, na base da negociação com estratos superiores, em posições subalternizantes. Basta ver que quatro dos pesquisados são oriundas do estado de Minas Gerais, dois de São Paulo e dois do Nordeste. E nos relatos sobressaem mostras nesses intelectuais, desde a infância na escola, o gosto pela arte/cultura, pela religião, bem como um senso de ativismo social e apurada sociabilidade; elementos trazidos de seus habitus familiares também.

Em todos esses casos (estudo, cultura e pobreza familiar), talvez a exceção seja João Soares Caldas, oriundo do estado de Sergipe, mas que estuda Direito no Rio de Janeiro nos anos 1930, tornando-se advogado e procurador em Londrina, cujos fatos denotam boa situação financeira e cultural da família de origem. 
Todos os intelectuais aqui postos casaram-se (exceto Dom Geraldo Fernandes, por óbvio) e foram arrimos de suas novas famílias, com cônjuges dependentes deles (exceto Nitis Jacon, cujo marido trabalhou como médico), idem para seus filhos. Por isso, ganhar a vida se sobrepõe a veleidades intelectuais mais básicas. Essas questões são pouco manifestadas, mas precisam ser desbastadas e expostas.

A subalternidade na política vivida pelas famílias de origem foi continuada pelos intelectuais enfocados. Alguns até desenvolveriam negócios privados fora do âmbito cultural (Mario José Romagnolli, Delio Cesar, João Soares Caldas). Isso também pode ser creditado ao fato de a economia da cidade estar ainda muito ligada à agricultura (anos 1930-1970). Novamente, a diversidade após o final do século XX, que caracterizaria a sociedade brasileira como um todo, irromperia em modificação nesse cenário.

\section{Campos: lutas, concessões, conciliações}

Retomando o raciocínio de Bourdieu, segundo o qual um campo só dispõe de autonomia completa se nele existirem três condições (produtores especializados, instâncias de consagração e mercado para disseminação das obras), entendemos que, em Londrina, na ausência dos consumidores das produções/publicações, os pretendentes a escritor-intelectual nunca conseguiriam sobreviver, pois não havia tiragem suficiente para se manter apenas com isso. Uma das soluções seria o "mercado de empregos" oferecido pela imprensa. Isso explica ser ela o primeiro e, muitas vezes, único escoadouro de autores como Marinósio Trigueiros Filho, Delio Cesar, Edison Maschio e Zaqueu de Melo (este também foi empregado por igrejas, escolas e faculdades). Teriam de ser alocados em jornais e neles divulgar sua "arte" ou pena de aluguel. Tanto melhor se o jornal não for adversário de poderosos locais, do estado do Paraná ou do país.

Ou seja, foram hábeis em pôr seus "talentos" a serviço de outro "mercado de trabalho" possível: o do servir/atuar como voz, ainda que indireta, para poderosos de plantão, sejam municipais, estaduais, eclesiásticos, políticos ou partidos. Diferente do nível federal, ainda não havia na cidade um mercado de cargos públicos à disposição. Eram as margens de manobras que puderam aproveitar.

Nisso, há também que expormos haver limites até onde esses intelectuais pretendiam "revolucionar" o mainstream local ou com ele dialogar (enquanto "oposição consentida"). Como exposto, a distribuição desigual de capitais em um campo aquece a dinâmica da "esgrima" entre seus agentes, o que os faz desenvolver estratégias de conservação (da ordem) nesse campo. Assim, intelectuais que giram em torno do poder acabam sendo caracterizados pela cooptação. Então, operar com desenvoltura entre setores e políticos oligárquicos é fundamental para $\mathrm{o}$ 
${ }^{16}$ Para tais situações, Gisèle Sapiro aventa a seguinte hipótese: “(...) a politização do campo literário na França foi um meio de compensar a falta de profissionalização do ofício de escritor num momento de diferenciação e de especializac̃o das profissões particular os políticos, os jornalistas e os particular os politicos, os jomalistas e os cientistas -, que privam os homens de letras de alguns de seus domínios de competência, como a política, a história nacional, a moral e o estudo dos costumes, o conhecimento da vida psíquica etc. Um movimento de profissionalização se esboça, entretanto, a partir do século XIX" (SAPIRO, 2004, p. 98) intelectual ser "bem-sucedido" (os desejosos por prestígios, benesses e cargos, em Londrina). Sendo a maioria dos letrados enfocados de fora da cidade ou estranhos aos círculos e grupos de poder dela, tal se colocava como estratégia quase sine qua non.

Desse modo, alguns atuaram culturalmente no limite dos níveis institucionais, realizando, ao invés de obras literárias, apenas trabalhos na imprensa ou alguns poemas em obras coletivas e de circulação ínfima. São os casos de Dom Geraldo Fernandes e de Zaqueu de Melo. Aproveitando-se das estruturas políticas que suas denominações detinham (a de históricas intimidades com o poder) puderam construir por fora suas carreiras e se impor sutilmente; não foi pouco terem ajudado a construir colégios e universidades, como os dois religiosos o fizeram.

O mesmo vale para Delio Cesar (vereador, vice-prefeito, jornalista, empreendedor da mídia, incentivador de festivais esportivos e culturais) e Nitis Jacon (liderança portentosa na manutenção do FILO e bem-sucedida gestora na universidade e em outras instâncias culturais). De certa forma, o quadro também se repetiria com Marinósio Trigueiros Filho (se era rompido com algum poderoso, é porque tinha a proteção de outros, numa coragem "relativa"), João Soares Caldas (advogado, procurador, secretário municipal, membro de Rotary club e similares) e Mario José Romagnolli (vereador, poeta "popular" e pequeno empresário), ambos pacíficos e destituídos de "perigos" para criticar o establishment local. Por isso, a total liberdade ou independência total do intelectual deve sempre ser relativizada ${ }^{16}$

De outro lado, é nosso entendimento que as produções desses intelectuais (as quais não foram foco direto das análises) não refletem a vontade de seus autores em fazer um nome para se insurgir na política, ao menos. Em termos burocráticoinstitucionais, esses intelectuais passaram discretos pelos poucos cargos que disputaram - ou seja, o apetite político não era tão alto entre eles; o apetite pela produção cultural pareceu maior; e participar da política parecia ser uma "quase obrigação", a qual não se poderia fugir, sob pena de ficar absolutamente liquidado para qualquer outra atuação na vida (cultural, financeira, social etc.). Mario José Romagnolli, Delio Cesar e Zaqueu de Melo foram políticos, mas de atuações discretas e baixos cargos; por vezes, derrotados em eleições; Nitis Jacon foi gestora pública de diversas funções, mas derrotada no único cargo que disputou. Todos aparentam entender as relações com a política como um mal necessário para poder desenvolver a sua seara, a gestão das artes e da academia, as que lhes interessavam. Enquanto isso, Marinósio Trigueiros Filhos, Edison Maschio e Delio Cesar eram mais "profissionais" da imprensa que eles.

Já as refregas em que a maioria se envolve estão ligadas a questões políticas stricto sensu (ao menos até onde os relatos nos permitem entender). As queixas e derrotas mostram que desnudam o desânimo com tal universo; isso os libera para se dedicar mais às 
questões artístico-culturais ou educacionais, casos de Mario Romagnolli, Zaqueu de Melo, Marinósio Trigueiros Filho, Delio Cesar e Nitis Jacon. Coincidência ou não, ao se afastar das desgastantes querelas da política é que se tornam mais "produtivos", como Zaqueu de Melo, Nitis Jacon, Marinósio Trigueiros Filho, Edison Maschio e Delio Cesar. De qualquer forma, a ruptura absoluta com o establishment nunca pareceu estar no horizonte desses letrados.

Já disputas e rivalidades diretas ou relevantes entre esses intelectuais ou em "panelas", no sentido da produção cultural (e ou de um possível campo cultural), parecem não ter ocorrido; o mesmo se pode dizer em relação a filiações a movimentos literários nacionais. A luta era mesmo para se estabelecer ou sobreviver em relação aos poderes públicos locais, na imensa maioria das vezes.

\section{Indústria de consagrações e "mercados" possíveis}

Para consagrações na cidade concorriam ínfimas editoras, pequena e grande imprensa, concursos, número de publicações, partidos políticos, igrejas, universidades, sindicatos, clubes e até organizações políticas clandestinas. Sem contar os círculos de sociabilidade: no caso, a constituição do "cenáculo" (seita ou "panela"), artifício comum que intelectuais/artistas usam para fechar um grupo e fazer autoconsagrações, elogios mútuos etc Assim se dava a convivência na vida literária e cultural local. Mas a participação na militância política, a partir de meados da década de 1960 (suplantando a literatura propriamente dita), seria um diferencial, pela intensidade.

Desse modo, entendemos que as estratégias dos intelectuais londrinenses para projeção e legitimação são objetivas e relativamente conscientes. Mesmo porque, verificando suas histórias posteriores (após 1980), percebemos que alguns foram, sim, ambiciosos; e que auferiram prestígios e cargos, conforme as situações (políticas, econômicas e institucionais) permitiam. Nada foi por acaso e suas trajetórias de vida refletem essa "vontade de poder". Portanto, é lícito afirmar que manusearam com maestria as regras dos campos onde se enredaram.

Procuramos também constatar tendências: assim, tanto para um passado próximo, quanto para a atualidade, entendemos ter acertado ao entender que intelectuais se movem no âmbito de relações de poder, embora tal não seja explicitado, e gostam de aparecer como que guiados por impulsos altruístas, mostrando uma autoimagem baseada no princípio do desinteresse e do afastamento das questões materiais - coisa farsesca, posto que tais atores encontram-se expostos a forças, pressões e interesses (pessoais, de classe e de poder) como qualquer indivíduo. São homens e mulheres de carne e osso, que precisam sustentar a família, satisfazer ambições, buscar prazeres etc. Intelectuais/artistas não são entes superiores, e tornar-se produtor de cultura "a serviço" de poderosos é algo padrão, quase atemporal. 
Em termos de formação, os letrados/literatos de Londrina são, em geral, jornalistas, médicos, advogados, professores, líderes religiosos, pequenos empresários (entre outras formações) e que atuam também como escritores - mas escritores bissextos, diletantes, provincianos, amadores.

E a literatura em Londrina era, em boa medida, feita de crônicas e reportagens "literárias" em jornais sobre crimes chamativos ou violentos que interessavam mais pelos apelos aos baixos instintos e morbidez dos leitores do que pelo valor literário que poderiam encerrar; também por isso é rapidamente consumível, digerível e perecível. Isso diz menos respeito à literatura e mais sobre gêneros de imprensa, apenas.

Outra caracterização da literatura local é ser ingênua singela, naï, mambembe, provinciana, periférica, amadora artesanal e de fundo de quintal; em verdade, uma caricatura arremedo ou simulacro da atividade. E se não houve mercado consumidor, os produtores tampouco se esforçaram para criar um, ou fazer surgir uma demanda. Mas nada disso impediu o debruçamento sobre o tema, nem diminuiu a importância deste estudo, pois esta era a vida cultural possível (e real) do local à época.

De outro lado, dadas as ligações geográficas, históricas, econômicas e culturais de Londrina com o estado de São Paulo e sua capital (maiores até do que com Curitiba e o restante do Paraná), os intelectuais locais podem ter desejado, ao menos, copiar o caráter cosmopolita, arrojado e pouco dependente do poder público que os paulistas e paulistanos tinham - não com o mesmo sucesso, naturalmente. Isso pode ter se refletido nas expressões culturais dos intelectuais londrinenses, porque sua produção é feita, em boa medida, por indivíduos voluntaristas, empreendedores ou ligados a entidades (partidos políticos, denominações religiosas, imprensa regional ou alternativa, instituições educacionais). A proposição é lembrada pelas comparações com o caso da antiga capital federal, o Rio de Janeiro, onde empreendimentos e financiamentos públicos, por hegemônicos, criaram uma dependência de seus intelectuais perante o poder. Nesse item, ao contrário, há muito mais semelhanças com londrinenses e diferenças deles em relação aos paulistanos.

\section{Intelectuais dominados ou dependentes}

Por tudo isso, propomos que os atores estudados perfazem um "grupo" (ainda que não orgânico) caraterizado por ser constituído de intelectuais dominados/dependentes. Os seus integrantes se achegaram ou adentraram o establishment; transpuseram obstáculos, ou tentaram; suas trajetórias, para além 
das peculiaridades pessoais, evocam dramaticidades, heroísmos e sofrimentos no interior de assimétricas relações de poder. Não obstante, conseguiram, de alguma forma, expor suas criatividades, ainda que com pouca ou nenhuma ruptura estética (ou crítica social). Retomando Bourdieu, o campo intelectual é sempre ligado a um campo maior, o do poder: assim, fica exposto um incompleto ou muito distante processo de "autonomização" em um campo cultural da cidade.

Os letrados estudados (enquanto "grupo" e "geração") caracterizam-se também pelas poucas tentativas de serem desbravadores. Mediando com seus habitus e capitais, desenvolveram carreiras e obras a partir de sutis formas de inserção nos universos intelectual e de poder (neste, principalmente).

Nesse sentido, também procuraram regular/mediar a inserção num inexistente mercado de consumidores de obras com outro mercado, o constituído por diplomas/formações profissionais específicas. Ou seja, é uma "geração" em que jornalistaspublicistas-políticos (todos secundarizados), professores universitários e lideranças religiosas precisam atuar na produção artístico-literária (ou nelas se fazer representar, aparecer, manifestar-se), pelo fato de ainda não haver a devida profissionalização do escritor (que seria possível somente na geração seguinte, quando os nascidos nos anos 1940/1950 começam a vida letrada, nas décadas de 1960/1970, sob novas situações; mas isso é outra história).

Esse "grupo/geração" desenvolve, portanto, um tipo de produtor de cultura que se molda, dialoga e negocia com a realidade da forma como foi possível fazer no lugar e no momento. Não podemos afirmar categoricamente que tal aspecto seria característico dessa geração do pós-segunda guerra (os intelectuais enfocados nascem entre os anos 1910 e 1930; o auge de suas vidas e produções se dá entre os anos de 1940 a 1980, em geral), de estratos sociais em ascensão e de cidades periféricas. Mas é o que propomos. E a produção cultural reflete este quadro situacional, no limite.

Assim, desprezando as pequenas diferenças, podemos pensar num degradé ou numa disposição gradativa de nuances. Dentro desse gradiente, ficariam: os mais dominados e os menos dominados (ou mais rebelados) em relação aos poderes locais/estaduais. Os primeiros dizem respeito a Mario José Romagnolli, Dom Geraldo Fernandes, Zaqueu de Melo, João Soares Caldas e Nitis Jacon. Os segundos perfazem Marinósio Trigueiros Filho, Edison Maschio e Delio Cesar. 


\section{Considerações finais}

Todo o exposto aponta o acerto na escolha do recorte histórico que fomos levados a desenvolver: como é sabido, o fim do século XX e o início do século XXI expuseram, para as sociedades londrinense e brasileira, outras realidades e produções culturais, com a rotinização das formas produtivas, um mercado melhor constituído e nomes de perfis diferentes dos aqui postos.

Numa síntese, podemos dizer que a maior parte da história social dos intelectuais londrinenses do século XX foi construída na base de relações que mantiveram com grupos dirigentes locais. Como ensina Bourdieu, na lógica da economia das "trocas simbólicas", deve haver negociações entre diferentes posições sociais, o que implica deveres e obrigações - no caso, entre intelectuais (os dominados) para com um poder (o dominante) Quanto maior a capacidade dos intelectuais londrinenses de se relacionar com a prefeitura ou governos (com prestação de serviços, apoios políticos etc., manejando bem o capital de relações sociais), melhor se dariam. Assim, esses produtores de cultura de Londrina precisaram ligar-se aos donos do poder ou padecer, por inexistirem ou serem inexpressivos os mercados para o consumo de seus produtos.
Diferentes interesses (dentro de uma classe, como ideários liberais ou socialistas de alguns dos letrados, ainda que não exteriorizados) e diversidades de móveis em luta (vender livros, modificar a moral e costumes na cidade, vencer eleições, ajudar sua religião etc.) acabam por denotar relações de força entre esses atores sociais (dentro do dominado "campo cultural" local). Isso sugere que as obras desses intelectuais seriam "produtos" negociados entre escolhas/competências individuais e determinações sociais (limitações, constrangimentos, tensões e desenvolturas sociais)

Tais proposições se devem ao fato de a história social dos intelectuais nos séculos XIX/XX, de modo bem claro no Brasil, ter sido, em boa parte, construída na base de três questões: a) relações que eles mantiveram com grupos dirigentes; b) relações que mantiveram com personalidades de outras áreas (servindo como instâncias de consagração, as quais estavam presentes na imprensa, nas instituições religiosas e acadêmicas); c) as modalidades de inserção da literatura e de outras formas por eles produzidas, no contexto de algum “mercado". Em Londrina, isso não foi diferente. E essa é uma formatação ajustada à teoria bourdiana do campo.

Desse modo, entendemos ser o nosso estudo, de certa forma, inédito, posto que trabalhos similares enfocam capitais e grandes centros, enquanto este analisou uma produção cultural 
periférica. E a situação de Londrina (ter tal tipo de produção) é uma realidade similar ao restante do país, longe dos grandes centros.

Outra originalidade é termos verificado as relações entre as narrativas dos intelectuais estudados e suas experiências sociais, buscando, com isso, conexões entre o tecido cultural local e o seu processo de modernização, bem como ter tratado das condições sócio-históricas em que se constituiria um possível "campo cultural" numa média cidade brasileira, em determinado momento, o de meados do século XX.

Com essas reflexões a respeito de produtores de cultura da sociedade londrinense, pretendemos ter contribuído com interpretações sobre o passado dela, fazendo com que seu presente seja mais bem compreendido. Pretendemos também ter ajudado a desconstruir a ideia de que intelectuais seriam diferentes de outros atores/grupos nas sociedades em geral.

\section{Referências Bibliográficas}

AMARAL, Danilo do (coord.). Nitis Jacon. Disponível em $<$ http://teatrodegaragem.com/teatro-e-londrina-

historias/videos/nitis-jacon/>. Acesso em 20 jun. 2016.

ARRUDA, Maria Arminda do Nascimento. Metrópole e Cultura São Paulo no meio do século XX. Bauru (SP): EDUSC, 2001b.

ASSOCIAÇÃO PRÓ-MEMÓRIA DE LONDRINA E REGIÃO.

Londrina-PR, Brasil: raizes e dados históricos 1930-2004. Londrina: Ed. Humanidades, 2007.

BAHR, Julio E. João Soares Caldas, fundador da Academia de

Letras, Ciências e Artes de Londrina. Disponível em:
$<$ http://academia-de-letras-de-

londrina.blogspot.com.br/2014/10/discurso-de-agradecimento-dopresidente.html>. Acesso em: 17 fev. 2017.

BEGA, Maria T. S. Letras e Politica no Paraná: simbolistas e anticlericais na República Velha. Curitiba: Ed. UFPR, 2013.

BENATTI, Antônio P. $O$ Centro $e$ as Margens: boemia $e$ prostituição na "capital mundial do café" (Londrina: 1930 1970). 1996. 241 p. Dissertação (Mestrado em História) - Setor de Ciências Humanas, Universidade Federal do Paraná, Curitiba, 1996.

BERTAN, Tereza C. A Educação Confessional Protestante: Instituto Filadélfia de Londrina - 1944 a 1972. 1990. Dissertação (Mestrado em Educação). Faculdade de Educação, Universidade Estadual de Campinas, Campinas (SP), 1990.

BOURDIE U, Pierre. A Economia das Trocas Simbólicas. São Paulo: Perspectiva, 1974

BOURDIEU, Pierre. As Regras da Arte: gênese e estrutura do campo literário. São Paulo: Companhia das Letras, 1996.

BOURDIEU, Pierre. "Campo intelectual e projeto criador". In: POUILLON, Jean (org.). Problemas do Estruturalismo. Rio de Janeiro: Zahar, 1968, p. 105-145.

BOURDIEU, Pierre. Coisas Ditas. São Paulo: Brasiliense, 2004

BOURDIEU, Pierre. In: ORTIZ, Renato (org.). Bourdieu Sociologia. São Paulo: Ática, 1983.

BRANDES, Dom Orlando. "Dom Geraldo Fernandes, um "Bispo dos pobres"”. Diário Católico. 02 fev. 2013. Disponível em: $<$ http://www.diariocatolico.com.br/2013/02/dom-geraldo-

fernandes-um-bispo-dos.html>. Acesso em: 20 set. 2015.

CAMPOS, Regina M. G. Conservatórios Musicais de Londrina: um estudo em história da educação (1930-1965). 2009. Dissertação (Mestrado em Educação) - CECA, Universidade Estadual de Londrina, Londrina (PR), 2009.

CAVALHEIRO, Elisangela. "Arquidiocese de Londrina promove resgate da história de Dom Geraldo Fernandes". A12 Notícias. 27
2013.
Disponível
em

$<$ http://www.a12.com/noticias/detalhes/arquidiocese-de-londrina-

Dossiê Arte do Carnaval

Arquivos do CMD, Volume 6, N.1. Jul/Dez 2017 
promove-resgate-da-historia-de-dom-geraldo-fernandes $>$. Acesso em: 20 set. 2015

CERNEV, Jorge (org.). Memória e Cotidiano - Cenas do Norte do Paraná: escritos que se recompõem. Londrina: IPAC/UEL; MEC, 1995.

FERNANDES, Reginaldo Júnior. Revolução e Democracia: vivências e representações (1960-1980). 2012. Tese (Doutorado em História Social) - FFLCH, Universidade de São Paulo, São Paulo, 2012.

FRANCOVIG, Carlos. Ouro Verde e Café Quente: 50 anos de literatura em Londrina. Londrina (PR): O Autor, 2005.

GONÇALVEZ, Paulo de Tarso. "Contos londrinenses - leitura e interpretação da obra Escândalos da província de Edison Máschio, primeiro romance londrinense que retrata a sociedade na década de 50". DETARSOHISTORIA. 08 out. 2008. Disponível em $<$ http://detarsohistoria.blogspot.com.br/search?q=EDISON>.

Acesso em: 10 jun. 2016

GOUVEA, Marcos C. "Delio Nunes Cesar: 50 anos dedicados ao jornalismo e à vida cultural de Londrina". Gazeta do Povo, Curitiba (PR). $\quad 10$ fev 2015 Disponível em: $<$ http://www.gazetadopovo.com.br/servico/delio-nunes-cesar-50anos-dedicados-ao-jornalismo-e-a-vida-cultural-de-londrinaejt09wvs99zu2dqgb186jr9e6>. Acesso em: 10 jun. 2015.

GUIMARÃES, João I. D. "Entre o "ilustrado" e o "intelectua puro": considerações acerca das virtualidades e limites do modelo bourdiano de campo para analisar a primeira geração modernista de Minas Gerais". Arquivos do CMD: Dossiê Literatura e Memória, v. 3, n. 2, Ago-Dez 2015, p. 12-33. Disponível em $<$ http://www.culturaememoria.com.br/revista/index.php/cmd/index >. Acesso em: 20 jan. 2016.

ICAB. Londrina perde o escritor e advogado João Soares Caldas. 26 out. 2013.2 Disponível em:<http://ongartebrasil.blogspot.com.br/2013/10/londrina-perdeo-escritor-e-advogado_76.html>. Acesso em: 02 fev. 2017.
IPAC. Heimtal: o passado e o presente no vale dos alemães. Londrina: Grafman, 1993 (Cadernos do Patrimônio Cultural, Série Estudos, n.2).

LEITE, Yatiara da S. "Entretenimento como fator de desenvolvimento socioeconômico em Londrina". Revista F@ pciência, Apucarana-PR, v. 9, n. 7, p. 53-63, 2012.

LUPORINI Fabio. "A polêmica da marchinha da cachaça". Gazeta do Povo, Curitiba (PR). 16 fev. 2011. Disponível em: $<\mathrm{http}$ ://www.gazetadopovo.com.br/caderno-g/a-polemica-da-

marchinha-da-cachaca-drpw1cvk7ked9024apg7g781q > . Acesso em: 20 jul. 2015.

MANNHEIM, Karl. "O problema sociológico das gerações". In: FORACCHI, Marialice M. (org.). Mannheim - Sociologia. São Paulo: Ática, 1982, p. 67-95.

MARINHO, José Aparecido. A História do Festival de Teatro de Londrina (FILO) - 1968 a 2000. 2005. Dissertação (Mestrado em Letras) - Setor de Ciências Humanas, Universidade Federal do Paraná, Curitiba, 2005.

MARSON, Elzio dos Reis. No Limiar do Horizonte: manifestações e discursos divisionistas Norte/Sul e política integracionista no Paraná (1920-1975). 2005. Dissertação (Mestrado em História) Faculdade de Ciências e Letras de Assis, Universidade Estadual Paulista, Assis (SP), 2005.

MARTÍNEZ, Ana Teresa. "Entre el "notable" y el "intelectual": las virtualidades del modelo de campo para analizar una sociedad en transformación (Santiago del Estero, 1920-1930)". Cuadernos FHyCS-UNJu, n 30, 2006, p. 213-231.

MEIRA, Thomás A. B. “... Da Força da Grana que Ergue e Destrói Coisas Belas": uma etnografia dos circuitos de lazer noturno em Londrina-PR a partir do Bar Valentino. 2008. Dissertação (Mestrado em Antropologia) - FFLCH, Universidade de São Paulo, São Paulo, 2008.

MELHADO, Felipe C. Anti-heróis Entre Heróis: Marinósio Filho, boemia e jornalismo na Londrina do Eldorado. 2014. Dissertação (Mestrado em História) - CLCH, Universidade Estadual de Londrina, Londrina (PR), 2014. 
MELO, Carmen Silvia de. Zaqueu de Melo - Educador Obstinado São Paulo: Scortecci, 2014.

MENDONÇA, Maurício Arruda. Pioneiros do Teatro Londrinense - GPT: Grupo Permanente de Teatro (1957-1964). Londrina: Atrito Art , 2006

MENEZES, Regina. Delio Cesar (in memorian). 9 fev. 2015. Disponível em: <http://reginamenezes.com/2015/02/09/delio-cesarin-memoriam/>. Acesso em: 01 jul. 2016.

MICELI, Sergio. "Bourdieu e a renovação da sociologia contemporânea da cultura". Tempo social, Rev. Sociol. USP, São Paulo, v. 15 (01), p. 63-79, abr. 2003.

MICELI, Sergio. "Intelectuais e classe dirigente no Brasil (192045)". In: Intelectuais à Brasileira. São Paulo: Companhia das Letras, 2001, p. 69-291.

MICELI, Sergio. "Poder, sexo e letras na República Velha (estudo clínico dos anatolianos)". In: Intelectuais à Brasileira. São Paulo: Companhia das Letras, 2001b, p. 13-68.

NICASTRO, Isabela. "Cultura se faz presente". Portal do Servidor Aposentado da UEL. Disponível em:

$<\mathrm{http} / / /$ www.uel.br/portaldoaposentado/entrevista/entrevista 119.p hp>. Acesso em: 01 jun. 2016

ORTIZ, Renato. "Pierre Bourdieu: a procura de uma sociologia da prática”. In: Ciências Sociais e Trabalho Intelectual. São Paulo: Olho d'Água, 2002, p. 149-174.

OSTI, Claudio. "Delio Cesar, cidadão honorário". Odiario.com. 12 dez. $2013 . \quad$ Disponível em:

$<$ http://blogs.odiario.com/pacocacomcebola/2013/12/12/delio-

cesar-cidadao-honorario/>. Acesso em: 10 jul. 2015.

PAIVA, Marco A. C. "Um outro herói modernista". Tempo Social, Rev. Sociol. USP, São Paulo, v. 20 (02), p. 175-196, nov. 2008.

PASSIANI, Enio. Na Trilha do Jeca: Monteiro Lobato e a formação do campo literário no Brasil. Bauru (SP): EDUSC, 2003. PASSIANI, Enio; FROTA, Wander. "Entre caminhos e fronteiras: gênese do conceito de "campo literário" em Pierre Bourdieu e sua recepção no Brasil”. Estudos de Literatura Brasileira Contemporânea, n. 34. Brasília, jul./dez. 2009, p. 11-41.

PEDREIRO, Ranulfo. "O Lado B de Londrina". Gazeta do Povo, Curitiba (PR), 10 set. 2013. Caderno G. Disponível em: $<$ http://www.gazetadopovo.com.br/caderno-g/o-lado-b-de-londrinabmy3ffhga0dha86b4nogcdwsu $>$. Acesso em: 10 jun. 2015.

PEDRIALLI, José. O Poeta da Rebeldia. 06 out. 2011. Disponível em: $<\mathrm{http} / / / w w w . j o s e p e d r i a l i . c o m . b r / 2011 / 10 /$ o-poeta-darebeldia.html>. Acesso em: 01 jun. 2016.

PEDRIALLI, José. Poeta será Homenageado no Cemitério, à Noite. 18 out 2012. Disponível em:

<http://www.josepedriali.com.br/2012/10/livro-sera-lancado-nocemiterio-noite.html>. Acesso em: 01 jun. 2016.

PONTES, Heloisa. Destinos Mistos: os críticos do Grupo Clima em São Paulo (1940-1968). São Paulo: Companhia das Letras, 1998.

PREFEITURA DE LONDRINA. Dados Populacionais. Disponível em:

<http://www.londrina.pr.gov.br/index.php?option=com content\&vi ew $=$ article \&id=163\&Itemid=66> . Acesso em: 01 mar. $\overline{2015}$.

PROTA, Leonardo. Discurso de Agradecimento do Presidente da Academia Proferido da Câmara Municipal de Londrina. Disponível em: <http://academia-de-letras-delondrina.blogspot.com.br/2014/10/discurso-de-agradecimento-dopresidente.html>. Acesso em: 17 fev. 2017.

SAPIRO, Gisèle. "Elementos para uma história do processo de autonomização: o exemplo do campo literário francês". Tempo social, Rev. Sociol. USP, São Paulo, v. 16 (01), p. 93-105, jun. 2004.

SCHWARTZ, Widson. "Ascensão política e luta pelos cursos superiores". Folha de Londrina, Londrina, 04 jun. 2017. Caderno
Londrina
Disponível

<http://www.folhadelondrina.com.br/?id_folha=2-1-142---3-

1959.>. Disponível em: 04 jun. 2017.

TRIGUEIROS FILHO, Marinósio; TRIGUEIROS NETO,

Marinósio. História da Imprensa de Londrina (do Baú do Jornalista). Londrina: UEL, 1991.

Dossiê Arte do Carnaval

Arquivos do CMD, Volume 6, N.1. Jul/Dez 2017 
WEBER, Max. "Classe, estamento, partido". In: Ensaios de Sociologia. Org. e introd. de H. H. Gerth e C. Wright Mills. Rio de Janeiro: Zahar Editores, 1963, p. 211-228.

WEBER, Max. "Os letrados chineses". In: Ensaios de Sociologia. Org. e introd. de H. H. Gerth e C. Wright Mills. Rio de Janeiro: Zahar Editores, 1963b, p. 471-501.

WEBER, Max. "Sociologia da religião (tipos de relações comunitárias religiosas)". In: Economia e sociedade: fundamentos da sociologia compreensiva. Trad. Regis Barbosa e Karen E. Barbosa. Brasília: Editora UnB, 1999, p. 279-418, Vol. 1. 